\title{
A Preliminary Microscopical Study of Honey Pollen of Two North Eastern States of India
}

\author{
Chittaranjan Naskar ${ }^{1, *}$, Satadip Sarkar ${ }^{2}$ \\ ${ }^{1}$ Madarat Popular Academy, India \\ ${ }^{2}$ Ex-Associate Professor, Department of Botany, Presidency College, Kolkata (now Presidency University) Chitaranjan Naskar, \\ Madarat Popular Academy, India
}

Received September 13, 2020; Revised October 26, 2020; Accepted November 19, 2020

\section{Cite This Paper in the following Citation_Styles}

(a): [1] Chittaranjan Naskar, Satadip Sarkar, "A Preliminary Microscopical Study of Honey Pollen of Two North Eastern States of India," Advances in Zoology and Botany, Vol. 9, No. 1, pp. 1 - 7, 2021. DOI: 10.13189/azb.2021.090101.

(b): Chittaranjan Naskar, Satadip Sarkar (2021). A Preliminary Microscopical Study of Honey Pollen of Two North Eastern States of India. Advances in Zoology and Botany, 9(1), 1 - 7. DOI: 10.13189/azb.2021.090101.

Copyright $\bigcirc 2021$ by authors, all rights reserved. Authors agree that this article remains permanently open access under the terms of the Creative Commons Attribution License 4.0 International License

\begin{abstract}
The present study is a firsthand attempt to decipher the pollen pictures of honey samples from two north- eastern states of India for their botanical origin and geographical source through Melissopalynology. The samples for this study were collected from Sairang Village, Mizoram and Wokha Village, Nagaland respectively maintaining an aseptic condition to avoid any contamination. The study revealed the nature of honey samples, unifloral or multifloral type and their frequencies in each sample. Upon analyses, the samples were also categorized based on the frequencies of the different morphotypes present in the samples which in turn indicated the partial vegetational picture of that area. The botanical origin has been indicated as far as possible of the samples, but it could not be possible to identify the geographical source of origin because of complete absence of any detailed published work on vegetational pictures of these states. The aim of this study is to characterisation and categorisation of honey samples for labelling their quality and quantity of the pollen content in honey samples along with their possible origin could be efficiently utilized for upliftment of financial status of the rural inhabitants of states.
\end{abstract}

Keywords Honey, Pollen, Flora-type, Characterization, Categorisation

\section{Introduction}

The Nature produces four vital sources of elements for survival of honeybees. They are water, resin, nectar and pollen. Pollen is the bee's major source of proteins, fatty substances, minerals and vitamins Gary [1] for the growth of larvae and young adult bees Dietz [2]. To prevent bacterial growth and defer the pollen germination time, a phytocidal acid is added and packed into the comb by the bees. This "bee bread" (i.e., stored pollen) are ready for later consumption by the young bees. Scientific studies on honeys have been conducted on the contents, including pollen by many workers since the year 1930 Zander [3]. Various workers throughout the world conducted different researchers on various aspects of Melissopalynology such as bee botany, bee genetics and breeding, bee chemistry and pathology, improvement in routine management practices etc. Pollen can be used as an essential tool for the analyses of honey.

Taxa of pollen are used to indicate the floral nectar sources utilized by bees to produce honey Louveaux [4]

Present study is a firsthand attempt on pollen analyses of squeezed honey samples collected from Sairang forest, Aizwal, Mizoram and from a village near Wokha town, Nagaland. Samples were collected aseptically during autumn time from the above-mentioned places.

The present area of work is envisaged to explore the possibility of using melissopalynology for: 
1) Indicating the botanical origin of pollen grains.

2) Identifying the geographical source of origin.

3) Verifying and labelling the honey samples as to the major and minor nectar sources.

This information has commercial value because honey of a dominant floral type can fetch a higher price than the honey of mixed or unknown floral sources.

\section{Materials and Methods}

Samples were collected aseptically during autumn season. One area of collection was Longsa village of Wokha District, Nagaland. The other area was Sairang village, Aizwal, Mizoram. The honey samples were squeezed from honeycomb of Apies florea.

The technique for extraction of pollen was followed according to the methodology recommended by Internal Commission for Bee Botany Louveaux [4]. Ten grams of honey sample was diluted with $20 \mathrm{ml}$. of distilled water and heated slightly to $38^{\circ} \mathrm{C}$ in a water bath and then stirred well to ensure a uniform mixing of pollen. It was centrifuged for 10 minutes at approximately 2500 r.p.m to ensure complete sedimentation of the pollen. Some authorities recommend 4000 r.p.m for centrifugation Low [5]. Half of the total samples were acetolysed Lieux [6] for 10 to 15 minutes at $100^{\circ} \mathrm{C}$ to keep the chances of recovering monocot pollen from the samples, if any.

Then glycerine in diluted form was added to store residues (of both acetolysed and unacetolysed) in vials with screw tops. These residues were thoroughly mixed before preparing microscopic studies for analysis.

Single grain preparations were done mainly for identification of pollen types under oil-immersion lens of a microscope and eventual photomicrography for documentation Faegri [7]. The factor for measurement in most cases was $3.2 \mu \mathrm{m}$. for one micrometer division. For photomicrography, a Magnus trilocular microscope was used.

\section{List of Pollen Grain Types Recovered}

\section{Sairang}

Inaperturate -- Aristolochia sp (Aristolochiaceae)

Monoporate reticulate - Musa sp (Musaceae)

Tricolpate reticulate - unidentified type

Tricolporate echinate - Bidens sp (Asteraceae)

Monoporate psilate - wild grasses (Poaceae)

Tricolporate echinate-Tridax sp (Asteraceae)

Pentaporate psilate -Alnus sp (Betulaceae)

Hexacolporate reticulate-Hyptis sp (Lamiaceae)

Tetrapororate reticulate-Caprinus sp (Betulacea)

Triporate - Alangium sp (Alangiaceae)

\section{Wokha}

Tricolpate psilate - Prunus sp (Rosaceae)

Tetrapororate reticulate-Caprinus sp (Betulacea)

Tricolporate reticulate - Gnaphalium $s p$ (Asteraceae)

Tetracolporate prolate - Citrus sp (Rutaceae)

Tripororate- Betula sp (Betulaceae)

Hexacolporate reticulate-Hyptis sp (Lamiaceae)

Tricolporate reticulate- Semecarpus sp (Anacardiaceae)

Pentapororate reticulate-Alnus sp (Betulaceae)

Inaperturate echinate-Canna sp (Cannaceae)

Triporate reticulate- Kleinhovia sp (Sterculiaceae) 


\section{PLATE 1}
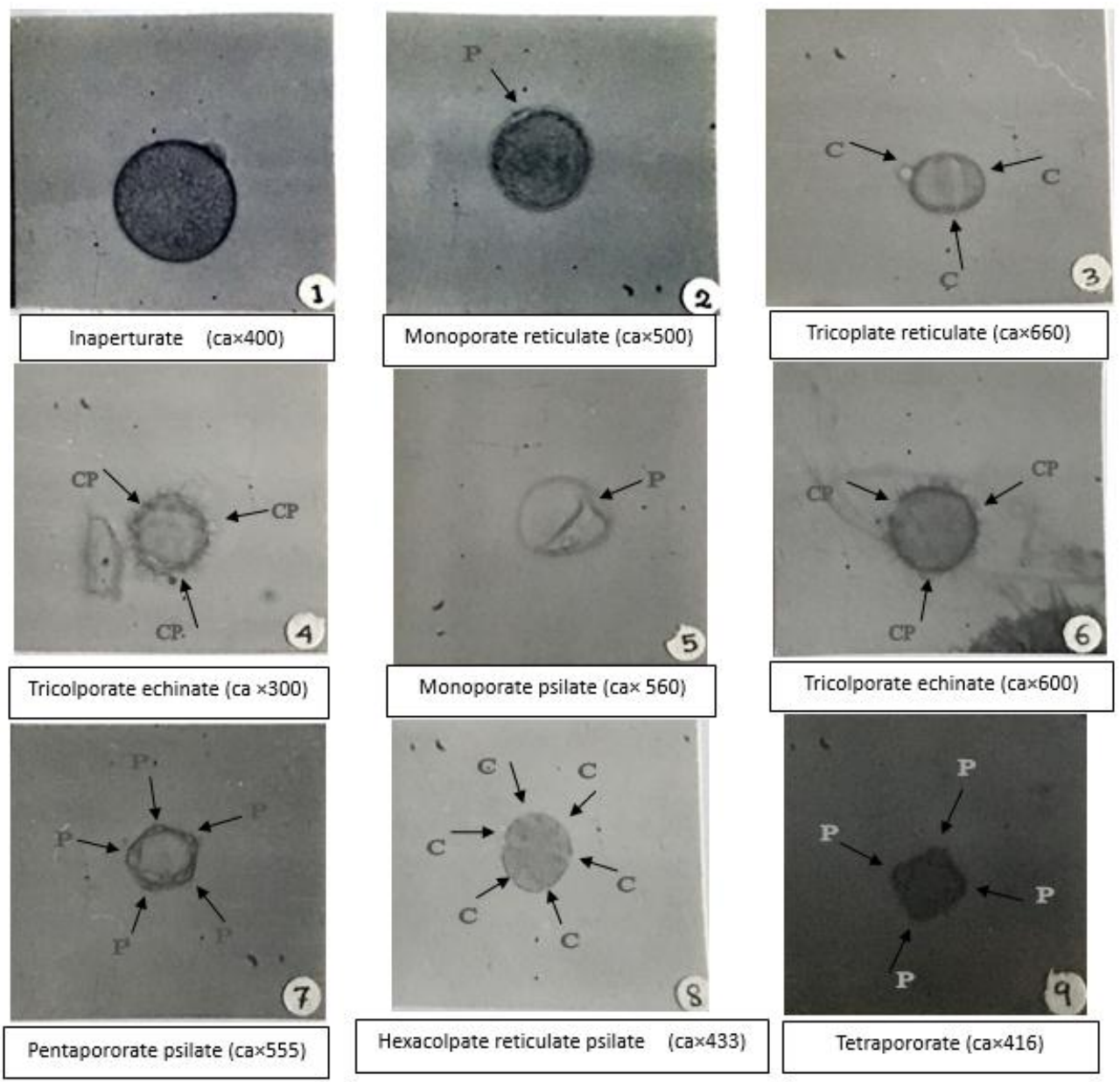

Tricolporate echinate (ca×600)
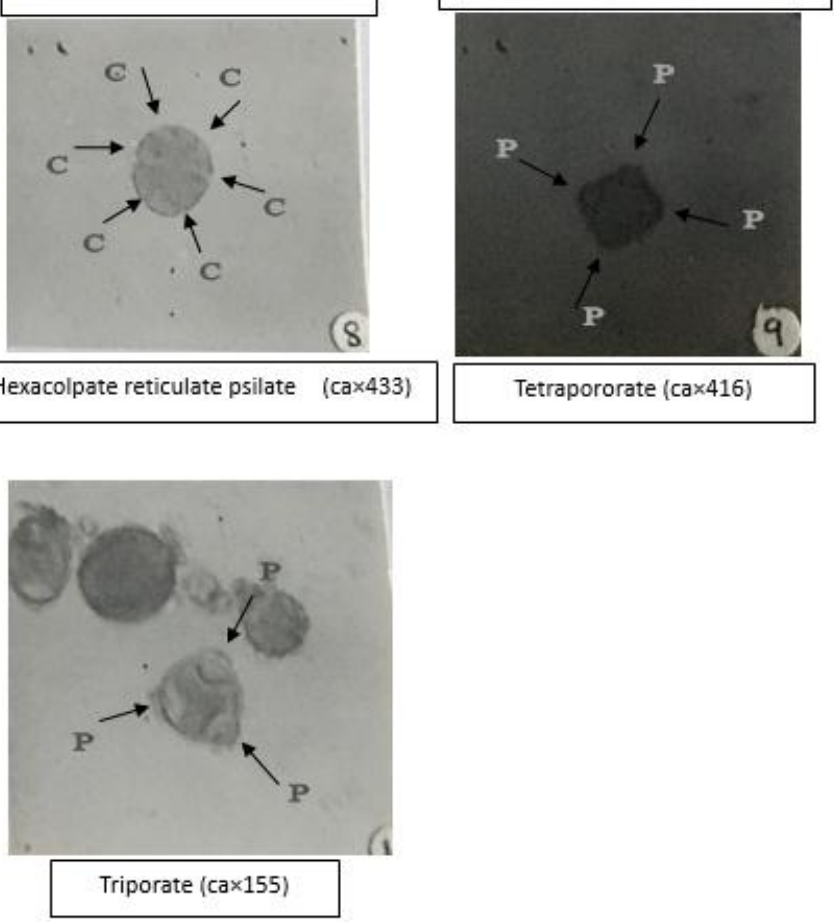

Figure 1. $\mathrm{C}$-colpus, $\mathrm{P}$ - pore, $\mathrm{CP}$ - colporate 


\section{PLATE 2}
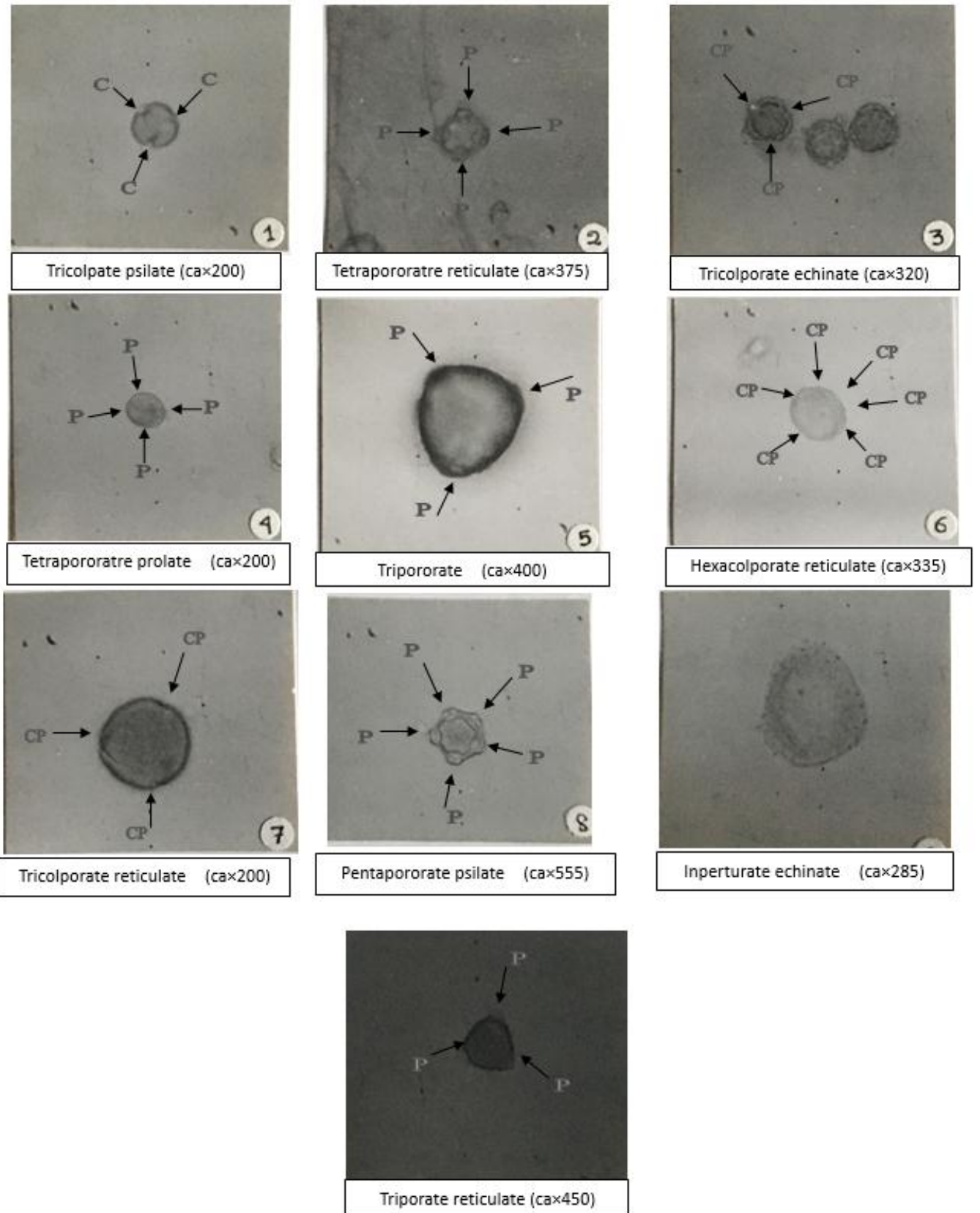

Figure 2. $\mathrm{C}$ - colpus, $\mathrm{P}$ - pore, $\mathrm{CP}$ - colporate

\section{Descriptions}

\section{Sairang Forest, Aizwal, Mizoram}

\section{Aristolochia (Aristolochiaceae)}

Pollen grain inaperturate, spheroidal, $40-45 \mu \mathrm{m}$ wide, exine 1-2 $\mu \mathrm{m}$. thick, tectate, sexine reticulate, tectum scabrate.

\section{Musa (Musaceae)}

Pollen grain monoporate, spheroidal, $20 \mu \mathrm{m}-30 \mu \mathrm{m}$. wide, pore $4 \mu \mathrm{m}$ wide annulate, exine $1 \mu \mathrm{m}$ thick, tectum with slightly scabrate processes, nexine thinner than sexine.

\section{Unidentified type}

Pollen grain tricolporate, prolate, length $14 \mu \mathrm{m}-18 \mu \mathrm{m}$ $\mathrm{X}$ bredth $10 \mu \mathrm{m}-12 \mu \mathrm{m}$, colpi long $3 / 4$ of the length of the grain, exin thin $1 \mu \mathrm{m}$ thick, sexine reticulate.

\section{Bidens (Asteraceae)}

Pollen grain tricolporate, subspheroidal, $35 \mu \mathrm{m}-40 \mu \mathrm{m}$ 
long X $22 \mu \mathrm{m}-25 \mu \mathrm{m}$ broad, ora transversely elliptic, colpi long as polar axis, echini $5 \mu \mathrm{m}$ long, exine $2 \mu \mathrm{m}$ thick, sexine granulate, usually with LO pattern.

\section{Monoporate wild (Poaceae)}

Pollen grain monoporate, spheroidal, $24 \mu \mathrm{m}-28 \mu \mathrm{m}$ wide, pores circular, $2 \mu \mathrm{m}$ in diameter with $2 \mu \mathrm{m}-4 \mu \mathrm{m}$ thick annulus, exine $2 \mu \mathrm{m}$ thick, sexine psilate.

\section{Tridax (Asteraceae)}

Pollen grain tricolporate, subspheroidal, grain $25 \mu \mathrm{m}-$ $30 \mu \mathrm{m}$ wide, colpi $20 \mu \mathrm{m}-22 \mu \mathrm{m}$ long x $1 \mu \mathrm{m}-2 \mu \mathrm{m}$ broad, ora circular $1.5 \mu \mathrm{m}$ wide, exine $3 \mu \mathrm{m}-4,0 \mu \mathrm{m}$ thick, echini $2.5 \mu \mathrm{m}-4 \mu \mathrm{m} \times 1.5 \mu \mathrm{m}-2.5 \mu \mathrm{m}$, sexine granulate.

\section{Alnus (Betulaceae)}

Pollen grain tetra pororate, oblate, rectangular in polar view, length $14 \mu \mathrm{m}-18 \mu \mathrm{m}$ x $26 \mu \mathrm{m}-30 \mu \mathrm{m}$ broad, aperture vestibulum type, ora circular, connected with arcus, exine thick $2 \mu \mathrm{m}-3 \mu \mathrm{m}$ differentiated into thin nexine and $1 \mu \mathrm{m}$ thick sexine, psilate.

\section{Hyptis (Lamiaceae)}

Pollen grain hexacolpate, subprolate, $20 \mu \mathrm{m}-30 \mu \mathrm{m}$ wide, exine thickened at two poles, $1.5 \mu \mathrm{m}-2 \mu \mathrm{m}$ thick, sexine finely reticulate at two poles, coarse at equator with OL pattern, nexine thinner than sexine.

\section{Caprinus (Betulaceae)}

Pollen grain tetra porate, oblate spheroidal, $20 \mu \mathrm{m}-24 \mu \mathrm{m}$ long $\times 25 \mu \mathrm{m}-30 \mu \mathrm{m}$ broad, ora crassimarginate, exine $1 \mu \mathrm{m}-2 \mu \mathrm{m}$ thick, tectum striato-reticulate, aperture drop type, nexine as thick as sexine.

\section{Alangium (Alangiaceae)}

Pollen grain tricolporate, suboblate $60 \mu \mathrm{m}-65 \mu \mathrm{m}$ wide, colpi $2 / 3$ of the polar axis, aperture drop type, ora circular, exine $2 \mu \mathrm{m}-3 \mu \mathrm{m}$ thick, sexine rugulo-reticulate, OL pattern, nexine thinner than sexine.

\section{Longsa VillageWokha, Nagaland}

\section{Prunus (Rosaceae):}

Pollen grain tricolporate, prolate, $35 \mu \mathrm{m}-40 \mu \mathrm{m}$ long $\mathrm{X}$ $30 \mu \mathrm{m}-35 \mu \mathrm{m}$ broad, aperture common type, exine usually $1 \mu \mathrm{m}-2 \mu \mathrm{m}$ thick, ora transversely elliptic, sexine granulate, nexine thinner than sexine.

\section{Caprinus (Betulaceae):}

Pollen grain tetra porate, oblate spheroidal, $18 \mu \mathrm{m}-22 \mu \mathrm{m}$ long $\mathrm{x} 22 \mu \mathrm{m}-28 \mu \mathrm{m}$ broad, ora crassimarginate, exine $1 \mu \mathrm{m}-2 \mu \mathrm{m}$ thick, tectum striato-reticulate, aperture drop type, nexine as thick as sexine

\section{Gnaphalium (Asteraceae)}

Pollen grain tricolporate, sub-spheroidal, $20 \mu \mathrm{m}-25 \mu \mathrm{m}$ long X $18 \mu \mathrm{m}-22 \mu \mathrm{m}$ broad, colpi nearly long as polar axis, ora circular $3 \mu \mathrm{m}-4 \mu \mathrm{m}$, exine more than $1.5 \mu \mathrm{m}$ thick, echine $2 \mu \mathrm{m}$ long $\mathrm{X} 2 \mu \mathrm{m}$ at base.

\section{Citrus (Rutaceae)}

Pollen grain tetracolporate, subprolate, $35 \mu \mathrm{m}$ wide, aperture common type, colpi usually long, ora transversely parallel, exine $1 \mu \mathrm{m}-2 \mu \mathrm{m}$ thick, sexine finely reticulate, lumina less than $1 \mu \mathrm{m}$ wide.

\section{Betula (Betulaceae)}

Pollen grain tripororate, oblate, sub-triangular in polar view. Mesocolpium diameter $50 \mu \mathrm{m}$ - $55 \mu \mathrm{m}$ and apocolpial diameter $30 \mu \mathrm{m}-32 \mu \mathrm{m}$.Pores $10 \mu \mathrm{m}-12 \mu \mathrm{m}$ in diameter. Exine $2.5 \mu \mathrm{m}-3 \mu \mathrm{m}$ thick, not differentiated, pores with annulus formed by the exine wall. Exine finely granulate.

\section{Hyptis (Lamiaceae)}

Pollen grain hexacolpate, subprolate, $18 \mu \mathrm{m}-28 \mu \mathrm{m}$ wide, exine thickened at two poles, $1.5 \mu \mathrm{m}-2 \mu \mathrm{m}$ thick, sexine finely reticulate at two poles, coarse at equator with $\mathrm{OL}$ pattern, nexine thinner than sexine.

\section{Semecarpus (Anacardiaceae)}

Pollen tricolporate, prolate, spheroidal in polar view, $45 \mu \mathrm{m}-55 \mu \mathrm{m}$ long X $25 \mu \mathrm{m}-30 \mu \mathrm{m}$ broad. Colpi $30 \mu \mathrm{m}-35$ $\mu \mathrm{m}$, pores lalongate, exine $1 \mu \mathrm{m}-2 \mu \mathrm{m}$ thick, differentiated into nexine and sexine, sexine striate.

\section{Alnus (Betulaceae)}

Pollen grain tetra pororate, oblate, rectangular in polar view, length $12 \mu \mathrm{m}-17 \mu \mathrm{m}$ x $24 \mu \mathrm{m}-29 \mu \mathrm{m}$ broad, aperture vestibulum type, ora circular, connected with arcus, exine thick $2 \mu \mathrm{m}-3 \mu \mathrm{m}$ differentiated into thin nexine and $1 \mu \mathrm{m}$ thick sexine, psilate.

\section{Canna (Cannaceae)}

Pollen grain inaperturate, $65 \mu \mathrm{m}-70 \mu \mathrm{m}$ wide, exine 0.5 $\mu \mathrm{m}$ thick, tectum with echinate processes, spines $2 \mu \mathrm{m}-3 \mu \mathrm{m}$ longX $2 \mu \mathrm{m}-2.5 \mu \mathrm{m}$, sexine granulate.

\section{Kleinhovia (Sterculiaceae)}

Pollen grain triporate, oblate, $16 \mu \mathrm{m}-20 \mu \mathrm{m}$ longX $24 \mu \mathrm{m}-28 \mu \mathrm{m}$ broad, aperture atrium type, pores circular $3 \mu \mathrm{m}-4 \mu \mathrm{m}$, exine $1 \mu \mathrm{m}$ thick, sexine reticulate with OL pattern. 
POLLEN ANALYTICAL RESULTS SAIRANG FOREST, AIZWAL

\begin{tabular}{|c|c|c|c|}
\hline TYPE & $\begin{array}{c}\text { TOTAL NO OF } \\
\text { GRAIN/10gm }\end{array}$ & PERCENTAGE & $\begin{array}{c}\text { POLLEN } \\
\text { FREQUENCY }\end{array}$ \\
\hline Aristolochia $\mathrm{sp}$. & 250 & 1.17 & Rare \\
\hline Musa sp. & 6180 & 29.02 & Frequent \\
\hline Unidentified type & 120 & 0.56 & Rare \\
\hline Bidens $\mathrm{sp}$. & 3120 & 14.65 & Infrequent \\
\hline Tridax sp. & 3250 & 15.26 & Infrequent \\
\hline Poaceae $($ Wild $)$ & 600 & 2.81 & Rare \\
\hline Caprinus $\mathrm{sp}$. & 5620 & 26.39 & frequent \\
\hline Alangium $\mathrm{sp}$. & 1250 & 5.87 & Rare \\
\hline Hyptis $s p$ & 405 & 1.90 & Rare \\
\hline Alnus $s p$ & 745 & 3.49 & Rare \\
\hline TOTAL & 21540 & & \\
\hline
\end{tabular}

\section{LONGSA VILLAGE, NAGALAND}

\begin{tabular}{|c|c|c|c|}
\hline TYPE & $\begin{array}{c}\text { TOTAL NO OF } \\
\text { GRAIN/10gm }\end{array}$ & PERCENTAGE & $\begin{array}{c}\text { POLLEN } \\
\text { FREQUENCY }\end{array}$ \\
\hline Prunus $s p$. & 2100 & 13.08 & Infrequent \\
\hline Caprinus $s p$. & 900 & 5.60 & Rare \\
\hline Citrus $s p$. & 900 & 5.60 & Rare \\
\hline Gnaphalium $s p$. & 6480 & 46.38 & Predominant \\
\hline Betula $s p$. & 1800 & 11.22 & Infrequent \\
\hline Hyptis $s p$. & 1200 & 7.47 & Rare \\
\hline Semecarpus $s p$. & 90 & 0.56 & Rare \\
\hline Alnus $s p$. & 2400 & 14.95 & Infrequent \\
\hline Canna $s p$. & 120 & 0.74 & Rare \\
\hline Kleinhovia $s p$. & 56 & 0.34 & Rare \\
\hline TOTAL & 16046 & & \\
\hline
\end{tabular}

\section{Pollen frequency according to Louveaux [4]}

Pollen analytical results with their detailed number per $10 \mathrm{gm}$ of sample, percentage of each pollen grain and individual frequencies have been represented in a tabular form separately for two states to distinguish their pollen categories.

Sairang Forest samples revealed a "mixed floral type" of pollen in honey samples. The most prolific two types were well below $45 \%$ (The percentage that is considered as a base line to be tagged as a "predominant type"). So a composition of two frequent, two infrequent and two rare types of pollen frequency marked them as a "mixed floral type" and hence placed as "Category II".

Longsa Village samples from Nagaland on the other hand clearly showing a single predominant pollen grain of Gnaphalium sp. with $46.38 \%$ of representation, thus clearly representing as 'unifloral type' of honey. Considering the frequencies, pollen samples have been placed in "Category I"
Categorization of samples are based on Louveaux [4]

\section{Discussion}

The present investigation on microscopical study of honey pollen from the two north eastern states of India has been divided into two parts, namely (1) Analyses of honey samples for characterization of palynomorphs to identify their botanical origin along with geographical source and (2) cateroisation of honey samples of the two states based on pollen analytical results that have some practical implications in apiculture and to the bee botanists.

First part deals with the characterization of honey samples for their floral content for an understanding of the composition of the taxa and their proper identifications. A total of 20 species of pollen have been recorded from the two states including some common types. Out of the total pollen only three types (i.e. Alnus sp, Hyptis sp and Caprinus sp) has been recorded as common types between 
the two states which are altogether geographically situated wide part from each other. All the morphotypes have been described vividly for proper identification. Pollen grains were photomicrographed and presented as documentary evidence. Due to absence of any published account of vegetational picture of those areas, the identification of pollen grains found in samples became difficult. Hence identifications have been done up to genera. Even a few pollen grains could not be identified even up to genus category. Some unpublished account of the vegetation of those areas by the Forest Department, Government of India has been consulted to get an idea of the vegetational picture occurring there at present.

The second part of the study dealt with categorization of honey samples based on the results revealed in this first part. The results were compiled in a tabular form have been mentioned earlier. It has been observed that there was floral similarity between these sates (although separated by the state of Manipur in between them) in the presence of Hyptis sp, Alnus sp and Caprinusa sp and dominance of Asteraceae family pollen grains. But on the other hand, Longsa village, Nagaland produces category I type of pollen assemblage that has a greater demand as a honey because of its unifloral type of origin. Sairang village samples are of 'mixed floral type' with no dominant pollen grain in sample.

The study could not reveal the geographical origin of pollen grains mainly due to absence of any detailed published work on vegetation of those places. This work is the first report of those places using the meissopalynology for evaluation quality of honey samples. More studies on vegetational picture and melissopalynology could reveal a detail insight of honey samples that could be utilized for Apiculture in future for growth and development of rural economy of those areas.

\section{Acknowledgements}

We wish to express our sincere thanks to Shri Tarun Kumar Jana, a school teacher of Nagaland and Shri Lalthanpuia, a third-year student of presidency College from the state of Mizoram for providing the squeezed honey samples. My sincere thanks also to Shri Albert Solo, IFS, Ministry of Environment and Forests, Govt. of India for providing necessary information about forest flora of Nagaland.

\section{REFERENCES}

[1] Gary, N.E Activities and behaviour of honeybees. In: The Hive and the honeybee. Dadant \& Sons, Carthage, Illinosis PP. 185 - 264, 1975 .

[2] Dietz, A Nutrition of the adult honeybee. The Hive and the honey Bee. In Atkins, E.L., Grout, R.A. and Dadant \& Sons (eds.) The Hive and the Honey Bee. Carthage, Illinois, PP. 125-126, 1975

[3] Zander, E. Pollen gestaltung und Herkunftsbestimmung bei Bliitenhonig; Reichsfachgruppe Imker, Berlin. $1935^{*}$

[4] Louveaux et al, Methods of melissopalynology. Bee World, Vol. 51, No. 3 PP. $125-138,1970 . \quad$ DOI: https//doi.org/10.1080.0005772X/1970/11097312

[5] Low, N.H, Schweger, C., \& Spoms, P, Precautions in the use of melissopalynology; Journal of Apiculture Research, Vol. 28, No. 1 PP. 50-54, 1989. DOI:10.1080/00218839.1989.11 100820

[6] Liux, M.H. Acetolysis applied to microscopical honey analysis; Grana, Vol. 19, No. 1 PP. 57- 61, 1980. DOI: $10.1080 / 00173138009424988$

[7] Faaegri, K. and Iversen, J. Textbook of modern pollen analysis, $1^{\text {st }}$ ed, H.T. Waterbolk, 1950, PP - 168

[8] Louveaux et al, Methods of melissopalynology. Bee World, Vol. 59, No. 4 PP. 139-157, 1978. DOI:10.1080/0005772X. 1978.11097714

[9] Deodikar, G.B and Thakar, C.V. A pollen study of major honey yielding plants of Mahabaleshwar Hills. Apic.Lab. Bull. No. 1. PP. 1-8, 1953

[10] Sawyer, R Honey identification, Cardiff Academic Press, printed in Great Britain by J.W. Arrowsmith, Bristol, ISBN 1871254000, PP. 1-108

[11] Crane, E. "A book of honey", $1^{\text {st }}$ ed, Oxford University press, Oxford, 1980 P- 193.

[12] Louveaux, J, Maurizio, A. Vorwohl, G. Methods of melissopalynology. Bee World, Vol.59, No. 4 PP. 139-157, 1978. DOI:10.1080/000772X.1978.11097714 * Original not consulted.). 